\title{
EFFECT OF BLOOD PRESSURE ALTERATIONS ON INTRARENAL RED CELL-PLASMA SEPARATION ${ }^{1,2}$
}

\author{
By LAWRENCE S. LILIENFIELD ${ }^{3}$ AND JOHN C. ROSE 4 \\ (From the Cardiovascular Research Laboratory, Departments of Medicine and Physiology, \\ Georgetozen University Medical Center, Washington, D. C.)
}

(Submitted for publication February 4, 1958; accepted April 17, 1958)

Recent reports have provided evidence for the separation of red cells and plasma within the kidney (1-3). Pappenheimer and Kinter have proposed an ingenious theory of plasma skimming to explain this phenomenon (2). According to these authors the energy for the separation is derived from the arterial pressure. Hence, there should be less separation at low pressure, and more at higher pressure. To test the validity of this hypothesis, simultaneous red cell and plasma transit times through the kidney were measured at normal and at low arterial pressures in 12 mongrel dogs.

\section{METHODS}

Dogs weighing 8 to $12 \mathrm{Kg}$. were anesthetized with sodium pentobarbital, $25 \mathrm{mg}$. per $\mathrm{Kg}$. intravenously. The left kidney was exposed and the renal artery and vein dissected free. Renal nerves were sectioned in all cases. A ligature was placed around the renal artery and tightened for a few seconds. During this time, the renal vein was incised and a polyethylene catheter $(2.5 \mathrm{~mm}$. inside diameter) was tied into the renal segment. The free end of the catheter was rapidly connected to a similar catheter that had previously been inserted in a femoral vein. When the renal artery occlusion was released, blood was seen to surge out of the kidney into the femoral vein. Flow through the catheters was unrestricted, all connections having internal diameters the same as the polyethylene tubing. In effect, the procedure had established a long exteriorized renal vein (Figure 1 ).

In all experiments aortic pressure was continuously monitored using a strain-gage transducer and directwriting oscillograph.

Five $\mathrm{ml}$. of a saline suspension of the dogs' red cells previously labeled with 100 microcuries of $\mathrm{Cr}^{51}$, and washed free of any extracorpuscular $\mathrm{Cr}^{51}$ activity, was mixed with 20 microcuries of $I^{131}$ tagged human serum

1 Presented in part at the National Meeting of the American Federation for Clinical Research, Atlantic City, N. J., May 5, 1957.

2 Supported in part by the United States Public Health Service Grant H-2987 (National Heart Institute).

${ }^{3}$ Research Fellow, American Heart Association.

4 Work done in part during the tenure of an Established Investigatorship of the American Heart Association. albumin. One-half $\mathrm{ml}$. of this mixture was injected into the renal artery over a period of 2 to 5 seconds. Just prior to injection, the renal venous catheter was disconnected from its coupling to the femoral venous catheter and permitted to drain freely. From the start of injection until 60 seconds later, total renal blood flow was continuously collected at 2 or 5 second intervals into paraffined test tubes containing dried heparin solution.

Seven of the animals were then bled from the femoral artery until the blood pressure was reduced and stabilized at about one-half of the control level. During the bleeding and stabilization period, the renal venous catheter was reconnected to the femoral vein. The renal arterial injection of isotope mixture was then repeated with total renal venous blood collection at the low arterial pressure for 120 seconds. The blood pressure frequently fell further or rose slightly at the start of this collection period. However, only those cases in which the pressure was constant after the isotopes were injected are reported. In two additional experiments, hydralazine (1 mg. per $\mathrm{Kg}$.) was used to lower the blood pressure after the control measurement, and in one experiment, norepinephrine was continuously infused to raise the pressure after the control run. In two other experiments good control results were obtained, but as a result of technical difficulties low pressure curves were not obtained. However, these cases are included in the control series. In one further experiment the control blood samples were inadvertently contaminated with radioisotopes, but the low pressure (posthemorrhage) data are included.

Following collection of the samples, $0.5 \mathrm{ml}$. aliquots of whole blood were pipetted into glass vials. These were centrifuged and the red cells were washed three times with normal saline solution. The $\mathrm{Cr}^{51}$ activity of these washed aliquots was counted in a well-type scintillation counter. Their activity was expressed as $\mathrm{Cr}^{51}$ counts per ml. of whole blood.

The remaining blood in the collection tubes was centrifuged, and $0.5 \mathrm{ml}$. aliquots of the supernatent plasma were counted in a similar manner. Plasma activity was expressed as $\mathrm{I}^{131}$ counts per $\mathrm{ml}$. whole blood, after correcting for the hematocrit obtained by centrifugation of at least three representative specimens $(2,000 \times \mathrm{G}$ for 60 minutes).

From the $\mathrm{Cr}^{51}$ counts per $\mathrm{ml}$. in each sample, and its time of collection (corrected for delay in the collecting system catheter and using the midpoint of the injection period as zero time), the mean circulation time of the 


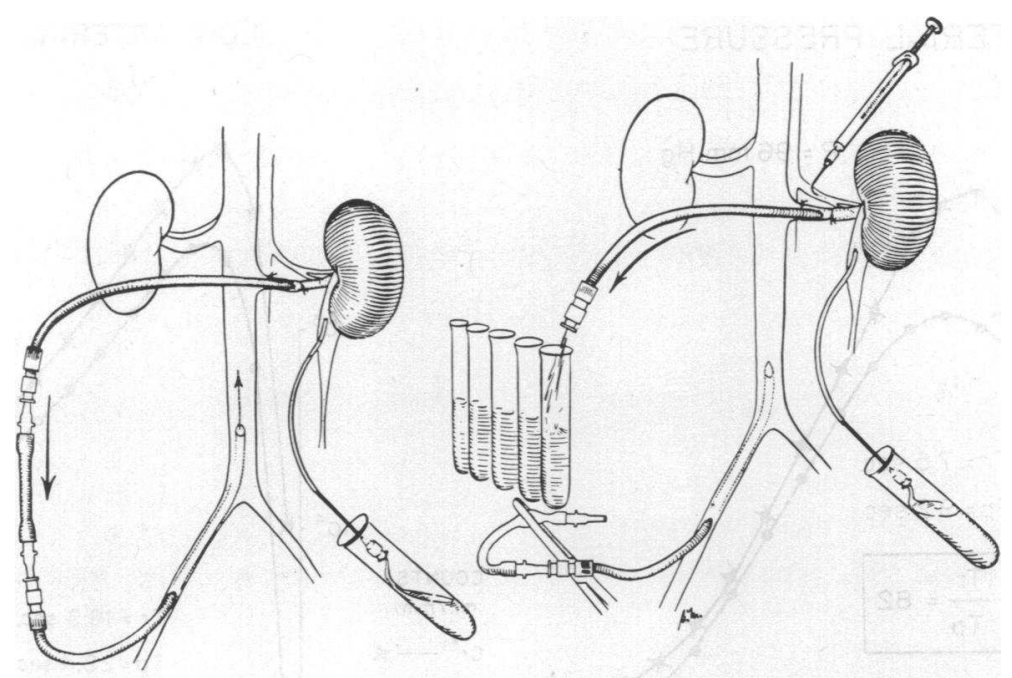

Fig. 1. Diagram of Procedure Used to Obtain Samples for Transit Time Calculations

red cells was determined. Similarly, from the $\mathrm{I}^{131}$ albumin counts the plasma mean circulation time was calculated. Curves were integrated to the time where the concentration had fallen to less than 1 per cent of the peak value (Figures 2 and 3 ).

Intrarenal hematocrits were calculated from the formula

$$
\text { HCT }_{\text {KID. }}=\frac{\frac{\mathrm{Tr}}{\mathrm{Tp}}}{\frac{\mathrm{Tr}}{\mathrm{Tp}}+\frac{1-\mathrm{HCT}_{\text {L.v. }}}{\text { HCT }_{\text {L.v. }}}},
$$

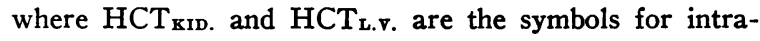
renal hematocrit and arterial hematocrit, and $\operatorname{Tr}$ and $\mathrm{Tp}$ are the mean transit times of red cells and plasma, respectively (3).
Renal resistance was determined from the recorded pressure and measured flow. The peripheral resistance unit (PRU) was defined as the arterial pressure in $\mathrm{mm}$. $\mathrm{Hg}$ divided by the flow in $\mathrm{ml}$. per second.

\section{RESULTS}

\section{Mean circulation time}

In all studies the mean transit time for red cells was slightly shorter than that of the plasma. In the control group the ratio of red cell to plasma transit times averaged $0.82 \pm 0.06$ (S.D.) (Table I). In the group of dogs whose blood pressure

TABLE I

Red cell and plasma (albumin) mean transit time at normal arterial pressure

\begin{tabular}{|c|c|c|c|c|c|c|c|c|c|}
\hline Dog & Pressure & Flow & Resistance & $\mathrm{Tr}^{*}$ & $T p \dagger$ & $\operatorname{Tr} / \mathrm{Tp}$ & HCTL.v. & HCTKID.‡ & $\begin{array}{c}\text { HCTKID./ } \\
\text { HCTL.v. }\end{array}$ \\
\hline $\begin{array}{l}n o . \\
0830 \\
1002 \\
1017 \\
1121 \\
1128 \\
1205 \\
1101 \\
1024 \\
0208 \\
0415 \\
0416\end{array}$ & $\begin{array}{c}m m . H g \\
125 \\
90 \\
130 \\
96 \\
100 \\
125 \\
125 \\
135 \\
125 \\
110 \\
110\end{array}$ & $\begin{array}{c}\text { ml. } / \text { sec. } \\
1.70 \\
0.81 \\
1.10 \\
1.00 \\
1.38 \\
1.47 \\
1.00 \\
1.04 \\
1.50 \\
1.06 \\
2.00\end{array}$ & $\begin{array}{r}P R U \\
74 \\
111 \\
118 \\
96 \\
72 \\
85 \\
125 \\
130 \\
83 \\
104 \\
55\end{array}$ & $\begin{array}{l}\text { sec. } \\
8.4 \\
9.2 \\
5.9 \\
7.5 \\
9.1 \\
1.9 \\
8.1 \\
9.3 \\
7.5 \\
8.3 \\
4.9\end{array}$ & $\begin{array}{r}\text { sec. } \\
9.9 \\
10.7 \\
6.7 \\
9.2 \\
11.1 \\
2.9 \\
9.6 \\
11.7 \\
8.8 \\
10.1 \\
5.9\end{array}$ & $\begin{array}{l}0.85 \\
0.86 \\
0.88 \\
0.82 \\
0.82 \\
0.66 \\
0.84 \\
0.79 \\
0.85 \\
0.82 \\
0.83\end{array}$ & $\begin{array}{c}\% \\
50.0 \\
43.3 \\
40.5 \\
52.0 \\
52.9 \\
45.5 \\
28.2 \\
48.4 \\
42.9 \\
45.0 \\
51.3\end{array}$ & $\begin{array}{c}\% \\
45.9 \\
39.2 \\
37.3 \\
47.1 \\
47.9 \\
35.8 \\
24.8 \\
42.6 \\
35.3 \\
40.2 \\
46.6\end{array}$ & $\begin{array}{l}0.92 \\
0.91 \\
0.92 \\
0.91 \\
0.91 \\
0.79 \\
0.88 \\
0.88 \\
0.82 \\
0.89 \\
0.91\end{array}$ \\
\hline Average & & 1.28 & & & & 0.82 & 45.5 & 40.2 & 0.89 \\
\hline S.D. & & & & & & \pm 0.06 & & & \pm 0.04 \\
\hline
\end{tabular}

* $\mathrm{Tr}$, mean transit time of red cells.

$\dagger$ Tp, mean transit time of plasma (albumin).

$\ddagger \mathrm{HCT}_{\mathrm{KID}}$. is calculated from formula given in text (see reference 3 ). 
HIGH ARTERIAL PRESSURE

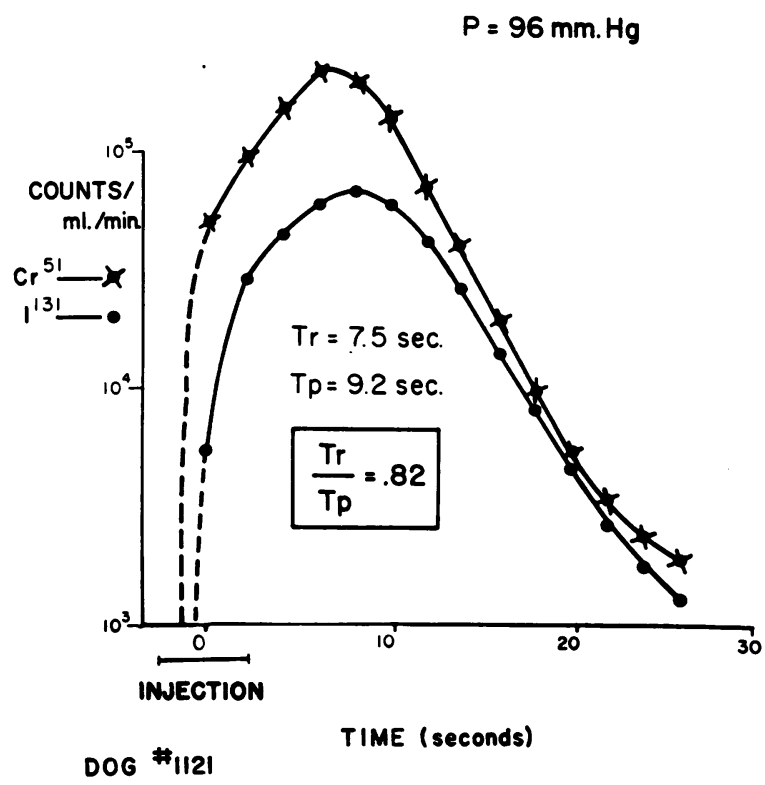

Fig. 2. Time-Concentration Curves Obtained FolLowing Injection of $\mathrm{CR}^{51}$ Labeled Red Cells AND $\mathrm{I}^{131}$ Labeled Albumin Into the Renal Artery

Zero time is taken as the midpoint of the injection period. Concentrations of samples are plotted at the midpoint of their collection period minus the catheter delay time. Catheter delay time was calculated from the volume of the collecting system in $\mathrm{ml}$. divided by the flow rate in $\mathrm{ml}$. per second. The ratio of transit times is 0.82 .

was lowered by hemorrhage this ratio averaged $0.79 \pm 0.06$ (Table II). Following lowering of the arterial pressure with hydralazine, the transit time ratios were 0.88 and 0.72 in the two animals studied. In the dog whose blood pressure was elevated by norepinephrine infusion the ratio was 0.88 (Table II).

\section{Intrarenal hematocrit}

The calculated intrarenal hematocrit in the control group was found to average $89 \pm 4$ per cent of the arterial hematocrit (Table I). This was not significantly altered by hemorrhage $(86 \pm 4$ per cent) or by hydralazine (93 and 82 per cent) (Table II). Norepinephrine raised the arterial hematocrit from 51.3 to 56.0 but the ratio of calculated intrarenal to large vessel hematocrit was
LOW ARTERIAL PRESSURE

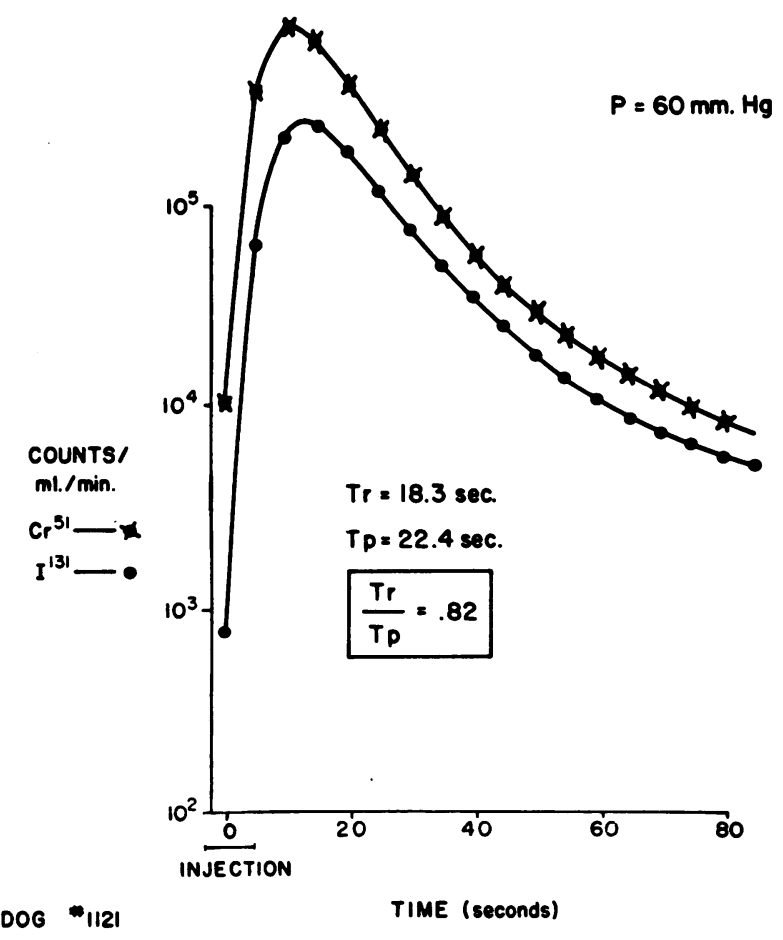

Fig. 3. Time-Concentration Curve from the Same Kidney as in Figure 2 Following Reduction in Arterial Blood Pressure by Bleeding

Note the transit time ratio remains 0.82 .

not significantly altered ( 0.91 , control; 0.94 after norepinephrine) (Tables I and II).

\section{Renal resistance}

In the six animals in whom control and posthemorrhage runs are reported, the renal resistance $(\mathrm{P} / \mathrm{F})$ rose from an average of $93 \mathrm{PRU}$ to 146 PRU (Tables I and II). In spite of the rise, no significant alterations occurred in intrarenal hematocrit. In the hydralazine treated dogs, there was a fall in calculated resistance but no significant change in intrarenal hematocrit. In the norepinephrine infused animal the renal resistance rose markedly from 55 to 825 PRU but the transit times ratio and hematocrit ratio were not signiîcantly altered.

\section{DISCUSSION}

The method of sample collection and catheter delay correction could result in an error in mean 
BLOOD PRESSURE EFFECT ON RED CELL-PLASMA TRANSIT TIMES

TABLE II

Red cell and plasma (albumin) mean transit time after pressure alterations

\begin{tabular}{|c|c|c|c|c|c|c|c|c|c|c|}
\hline Dog & Pressure & Flow & Resistance & $\operatorname{Tr}$ & $T p$ & $\mathrm{Tr} / \mathrm{T}_{\mathrm{p}}$ & HCTL.v. & HCTKID. & $\begin{array}{l}\text { HCTKID./ } \\
\text { HCTL.v. }\end{array}$ & $\begin{array}{l}\text { Method of } \\
\text { altering B.P. }\end{array}$ \\
\hline $\begin{array}{c}n o . \\
0830 \\
1002 \\
1017 \\
1121 \\
1128 \\
1205 \\
0920\end{array}$ & $\begin{array}{c}m m . H g \\
90 \\
70 \\
30 \\
60 \\
45 \\
30 \\
70\end{array}$ & $\begin{array}{c}\text { ml. } / \mathrm{sec} . \\
0.46 \\
0.29 \\
0.36 \\
0.49 \\
0.47 \\
0.22 \\
0.23\end{array}$ & $\begin{array}{r}P R U \\
196 \\
241 \\
83 \\
122 \\
96 \\
136 \\
304\end{array}$ & $\begin{array}{l}\text { sec. } \\
31.1 \\
21.4 \\
15.2 \\
18.3 \\
29.3 \\
10.5 \\
17.0\end{array}$ & $\begin{array}{l}\text { sec. } \\
36.6 \\
25.9 \\
19.8 \\
22.4 \\
37.5 \\
16.0 \\
20.8\end{array}$ & $\begin{array}{l}0.85 \\
0.83 \\
0.77 \\
0.82 \\
0.78 \\
0.66 \\
0.82\end{array}$ & $\begin{array}{c}\% \\
54.4 \\
42.4 \\
36.0 \\
54.1 \\
53.0 \\
45.5 \\
37.6\end{array}$ & $\begin{array}{c}\% \\
45.5 \\
37.9 \\
30.2 \\
49.1 \\
46.7 \\
35.5 \\
33.1\end{array}$ & $\begin{array}{l}0.84 \\
0.89 \\
0.84 \\
0.91 \\
0.88 \\
0.78 \\
0.88\end{array}$ & $\begin{array}{l}\text { Hemorrhage } \\
\text { Hemorrhage } \\
\text { Hemorrhage } \\
\text { Hemorrhage } \\
\text { Hemorrhage } \\
\text { Hemorrhage } \\
\text { Hemorrhage }\end{array}$ \\
\hline Average & & & & & & 0.79 & 46.1 & 39.7 & 0.86 & \\
\hline S.D. & & & & & & \pm 0.06 & & & \pm 0.04 & \\
\hline $\begin{array}{l}0208 \\
0415 \\
0416\end{array}$ & $\begin{array}{r}70 \\
50 \\
165\end{array}$ & $\begin{array}{l}1.33 \\
0.52 \\
0.20\end{array}$ & $\begin{array}{r}53 \\
96 \\
825\end{array}$ & $\begin{array}{r}8.3 \\
10.5 \\
10.0\end{array}$ & $\begin{array}{r}9.4 \\
14.5 \\
11.4\end{array}$ & $\begin{array}{l}0.88 \\
0.72 \\
0.88\end{array}$ & $\begin{array}{l}44.0 \\
45.0 \\
56.0\end{array}$ & $\begin{array}{l}40.9 \\
37.1 \\
52.7\end{array}$ & $\begin{array}{l}0.93 \\
0.82 \\
0.94\end{array}$ & $\begin{array}{l}\text { Hydralazine } \\
\text { Hydralazine } \\
\text { Norepinephrine }\end{array}$ \\
\hline
\end{tabular}

transit time determinations as large as one second, but would affect the red cell and albumin data identically. For this reason, no attempt was made to calculate the intrarenal blood volume from the transit time data. However, errors of one second affecting both red cells and albumin would not produce significant changes in the ratio of transit times at the ranges found in this study.

The plasma skimming theory of Pappenheimer and Kinter (2) predicts a change in the ratio of red cell to plasma transit times and a rise in intrarenal red cell concentration with alterations in blood pressure. In spite of marked reductions in velocity of blood flow through these kidneys from an average of $1.3 \mathrm{ml}$. per second at normal pressures to $0.36 \mathrm{ml}$. per second at low pressure following hemorrhage, the transit time ratio was not significantly changed. In addition, no rise in calculated intrarenal hematocrit was observed. Similarly, hydralazine or norepinephrine, though markedly affecting blood pressure, did not alter the transit time relationships significantly. Thus it appears that the intrarenal hematocrit is independent of blood pressure (Figure 4). Almost

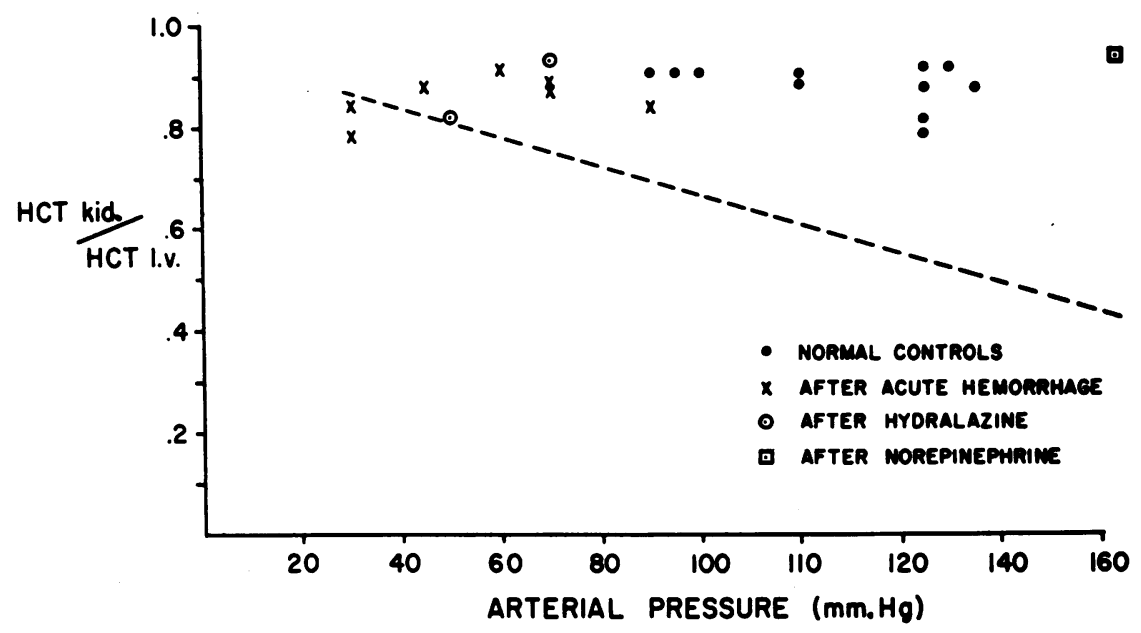

Fig. 4. Effect of Arterial Blood Pressure on Hematocrit

Ordinate, ratio of intrarenal hematocrit $\left(\mathrm{HTC}_{\mathbf{K I D}}\right)$ to large vessel hematocrit (HCT $\left.T_{\text {L.v. }}\right)$; abscissa, arterial blood pressure during sample collection period. The dotted line would be the relationship expected from the hypothesis proposed by Pappenheimer and Kinter (2). 
identical results have been reported by Ochwadt in studies with isolated blood-perfused kidneys (4). The changes in renal resistance that occurred following hemorrhage or drug administration must have resulted from vascular tone changes, rather than viscosity alterations due to intrarenal red cell concentration changes.

The transit times for red cells are somewhat less than that for plasma albumin at both high and low blood velocity. This observation argues against axial streaming or plasma skimming as the mechanism for the intrarenal red cell shunt. Some anatomic arrangement in the kidney must permit some red cells to traverse shorter paths than albumin entering at the same time. It is suggested that a long circuit pathway exists that permits mainly plasma or albumin to enter, and excludes red cells because of a very small entrance diameter. Recent observations reported from this laboratory provide evidence for an extravascular albumin space in the kidney which is rapidly equilibrated with the blood plasma $(5,6)$. Electron microscopic studies of the vascular bed of the rat kidney have demonstrated that both glomerular and peritubular capillaries are fenestrated with pores capable of permitting the passage of albumin (7). It seems likely that the long circuit albumin pathways are in reality part of the extravascular spaces in the kidney. The true intravascular hematocrit of the kidney may well be very close to that of the arterial blood. Further studies employing macromolecules as plasma indicators are now in progress to determine this.

\section{SUMMARY}

Simultaneous red cell and plasma albumin transit times through the kidney were measured in 12 mongrel dogs at normal arterial pressure and after pressure alteration by bleeding or drug administration (hydralazine, norepinephrine). In spite of marked changes in velocity of blood flow, no significant alterations in relative red cell to plasma transit times were observed. Calculated intrarenal hematocrits before or after acute bleeding were almost identical, and averaged 88 per cent of the arterial hematocrit. This study fails to support the plasma skimming theory of renal autoregulation. The evidence suggests the existence of long circuit plasma or albumin paths through the kidney which, at either normal or low pressure and velocity of flow, are too narrow at their entrance to permit passage of red cells.

\section{ACKNOWLEDGMENT}

The authors gratefully acknowledge the technical assistance of Miss Jean Pietras and Mr. Thomas F. Doyle.

\section{REFERENCES}

1. Allen, T. H., and Reeve, E. B. Distribution of "extra plasma" in the blood of some tissues in the dog as measured with $\mathrm{P}^{32}$ and T-1824. Amer. J. Physiol. 1953, 175, 218.

2. Pappenheimer, J. R., and Kinter, W. B. Hematocrit ratio of blood within mammalian kidney and its significance for renal hemodynamics. Amer. J. Physiol. 1956, 185, 377.

3. Lilienfield, L. S., Rose, J. C., and Porfido, F. A. Evidence for a red cell shunting mechanism in the kidney. Circulat. Res. 1957, 5, 64.

4. Ochwadt, B. Durchflusszeiten von Plasma und Erythrocyten, intrarenaler Hämatokrit und Widerstandsregulation der isolierten Niere. Pflüg. Arch. ges. Physiol. 1957, 265, 112.

5. Lassen, N. A., Longley, J. B., and Lilienfield, L. S. Concentration of albumin in the renal papilla. Clin. Res. 1958, 6, 154.

6. Lilienfield, L. S., Lassen, N. A., and Rose, J. C. The diverse distribution of red cells and albumin within anatomic regions of the kidney. Proc. Southern Society Clin. Research, Twelfth Annual Meeting, New Orleans, La., January 25, 1958, p. 32.

7. Pease, D. C. Electron microscopy of the vascular bed of the kidney cortex. Anat. Rec. 1955, 121, 701. 